1994-95 Annual Report

Association Of

C O L LEGE

\& RESEARCH

L I B R A R I ES

A D I V I S I O N O F THE AMERICAN LIBRARY ASSOCIATION

\title{
Charting New
}

DIRECTIONS FOR ACRL 


\title{
Message from the President
}

\author{
SUSAN K. MARTIN \\ ACRL's 56TH PREsIDENT
}

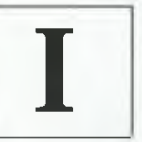

n 1994-95 ACRL and its members achieved several goals that will enable the organization to address the critical issues of library and information services in academic institutions in the late 20th century, and will position ACRL to cope with the challenges of the 21 st century.

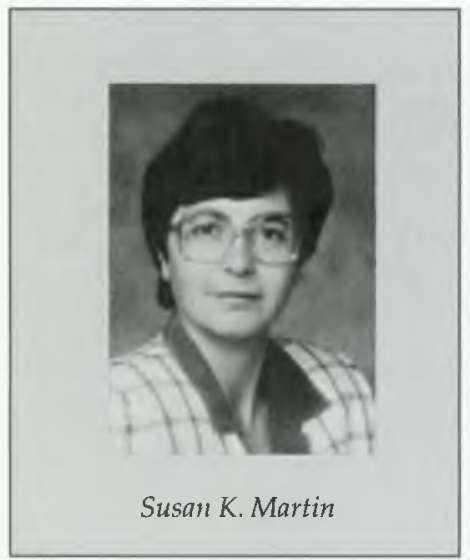

ACRL leaders and membership worked diligently during the past three years to replace the former five-year strategic plan (1987-92) with a new mission, vision, and strategic directions for ARCL for 1996-2001. In June 1995 the ACRL Board of Directors adopted the new Strategic Plan, and intends that its elements be used throughout the association's sections, committees, and roundtables to further the role of academic libraries and librarians in meeting the rapidly changing information needs of college and university communities.

The ACRL vision places the organization in a strong position to provide information services and resources and, in particular, suggests that academic librarians need to play a larger role in higher education and within the legislative process.

To this end, at the Midwinter Meeting in 1995 the ACRL Board of Directors voted to support ALA's Goal 2000 by donating $\$ 50,000$ toward the $\$ 1$ million goal; and the ACRL publication Choice matched that amount, allowing ACRL as a whole to provide ALA with a significant inauguration of one of the most innovative and foresightful programs in its history. When the Board announced its decision to Elizabeth Martinez, Executive Director of ALA, it did so with the provision that the ACRL contribution should go toward improved representation of academic libraries in Washington (a priority of ACRL's membership) and added focus on information policy and the role of library and information technologies in this country.

The creation of this vision and the strategic plan is due to the hard work of the ACRL leadership during the past three years-the section officers, committee chairs, chapters council, and Board of Directors. Meeting and discussing issues and priorities for half a day prior to each ALA Midwinter Meeting and Annual Conference, this group has come to understand and mutually agree upon the direction of the 


\section{Message from the President}

association. It is critical that this communication process continue; therefore, the leadership meetings at Annual Conferences and Midwinter Meetings will continue in an effort to assess the strategic plan and its impact on ACRL activities, and ultimately to begin to generate the next strategic plan.

ACRL in the future is likely to be different from ACRL today. The impetus to work more closely with other organizations involved with higher education, and the changing role of librarians on college and university campuses will contribute to making the organization more professional, more streamlined, and a force to be reckoned with in the arena of higher education. Members and staff alike are critically important in ensuring ACRL's success. We are moving in the right direction, and I thank all of you for playing a role in steering ACRL such that it makes a difference in the world.

\begin{tabular}{lrrrrr}
\hline \multicolumn{5}{c}{ ACRL MEMBERSHIP STATISTICS } \\
\cline { 3 - 6 } ACRL & Personal & $\begin{array}{c}\text { Organizational } \\
\text { Special }\end{array}$ & $\begin{array}{c}\text { Aug. 1995 } \\
\text { Total }\end{array}$ & $\begin{array}{c}\text { Aug. 1994 } \\
\text { Total }\end{array}$ & $\begin{array}{c}\text { \% increase/ } \\
\text { decrease }\end{array}$ \\
\hline ACRL & 9,638 & 1,077 & 10,715 & 10,379 & $3.23 \%$ \\
\hline AAMES & 397 & 71 & 468 & 468 & $0.00 \%$ \\
\hline AFAS & 239 & 24 & 263 & 251 & $4.78 \%$ \\
\hline ANSS & 529 & 84 & 613 & 590 & $3.89 \%$ \\
\hline ARTS & 819 & 112 & 931 & 940 & $-0.95 \%$ \\
\hline CJCLS & 884 & 262 & 1,146 & 1,112 & $3.05 \%$ \\
\hline CLS & 1,886 & 341 & 2,227 & 2,167 & $2.76 \%$ \\
\hline EALS & 263 & 6 & 269 & 12 & $0.00 \%$ \\
\hline EBSS & 1,147 & 197 & 1,344 & 1,379 & $-2.53 \%$ \\
\hline ECLSS & 698 & 43 & 741 & 610 & $21.47 \%$ \\
\hline IS & 3,799 & 466 & 4,265 & 4,126 & $3.36 \%$ \\
\hline LPSS & 676 & 114 & 790 & 789 & $0.12 \%$ \\
\hline RBMS & 1,622 & 194 & 1,816 & 1,879 & $-3.35 \%$ \\
\hline SEES & 247 & 59 & 306 & 313 & $-2.23 \%$ \\
\hline STS & 1,599 & 244 & 1,843 & 1,820 & $1.26 \%$ \\
\hline ULS & 5,666 & 351 & 6,017 & 5,991 & $0.43 \%$ \\
\hline WESS & 695 & 58 & 753 & 768 & $-1.95 \%$ \\
\hline WSS & 847 & 98 & 915 & 926 & $-1.18 \%$ \\
\hline
\end{tabular}




\section{Message from the Vice-President}

\section{Patricia SENN BreiviK \\ Vice-President / President-Elect}

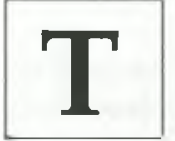

here is a great sense of urgency among ACRL Board members and myself this year. With the ACRL strategic plan hot off the press, we are conscious of the need to

produce some outcomes from the plan that are observable and mean-

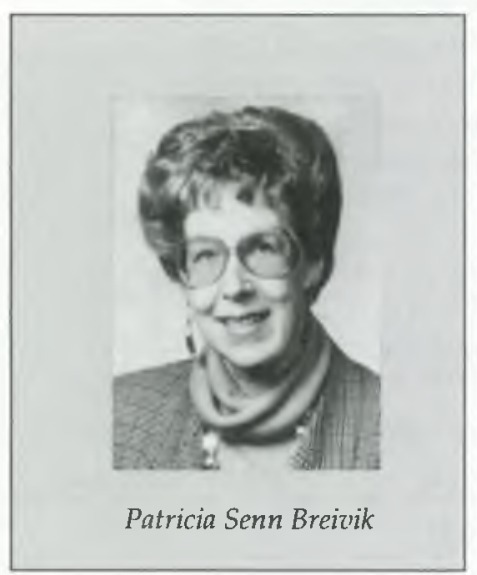
ingful to membership; and, on the other hand, we also know that most strategic plans fall far short of the hopes they engender, because organizations cannot or will not restructure their operations to support the new directions. Since our strategic plan is solidly based in ACRL membership's priorities and gives clear guidance for the future, the challenge for my year as ACRL president is to expedite progress on both fronts. To that end, here are some of the steps already taken.

\section{PROGRAM EFFORTS}

- In keeping with its goal as developer of people and practice, the ACRL President's Program this year will provide a multifaceted learning opportunity for conference participants and will also be packaged for use by chapters, library staffs, and other groups. The incoming president, Bill Miller, is already working with the ACRL Professional Education Committee to establish a mechanism to annually capture the best of ACRL programming at both the national (and chapter) levels for broader distribution.

- The President's Program theme for this year addresses professional development for the type of beyond-library-walls leadership necessary to accomplish ACRL's goals as partner advocate and player.

- A process has been identified for biannually working with other national organizations to identify key areas of mutual concern for the type of collaborative efforts to which goal as partner is directed. This will be tied into the newly restructured Council of Liaisons.

\section{CHANGES IN OPERATIONAL PROCEDURES}

All of the following changes address to some degree ACRL's goal as an effective organization. Some also address other goals as well.

- The ACRL Board is now taking responsibility for the planning process, and the Planning Committee has been eliminated. The Executive Committee had a meeting in October to wrestle with how to realign 


\section{Message from the Vice-President}

the planning process to drive budgeting in order to direct resources (financial, staff, and membership volunteers) toward the goals and strategic directions in the plan.

- All ACRL committees have been asked to re-examine their charges and make-ups in keeping with the Strategic Plan. Besides the elimination of the Planning Committee, the Membership and Professional Liaison Committees have already been completely restructured. Others are in the process of change; e.g., the Professional Education Committee is in the process of changing its focus to continuing professional education in keeping with ACRL's goal as developer of people.

- Since effective coordinated lobbying at the state and national levels is crucial to ACRL's goal as player and advocate, a taskforcechaired by Tom Kirk and made up of leadership from the Chapters Council and the Governmental Relations Committee-has been established.

\section{THE FUTURE}

There is so much more to be done and so many questions to be asked. How, for example, should ACRL and its chapters best complement each other's efforts in the four goal areas? How can the appointment procedure be modified so as to capture the best leadership from the chapters? How, in fact, can we maximize our limited human and financial resources to achieve the common good for the broadest number of our members in the priority (goals) areas identified by our members?

Hopefully, people across ACRL are already asking these questions and will seriously continue to do so at Midwinter. In this way, grassroots efforts can combine with Board efforts so progress can be expedited.

The Board is also committed to expanding normal communication efforts so that all concerned members, as well as ACRL unit and chapter leaders, will have the opportunity to be easily informed as progress is made and as operational changes are implemented. However, the key word is opportunity. We need your help in

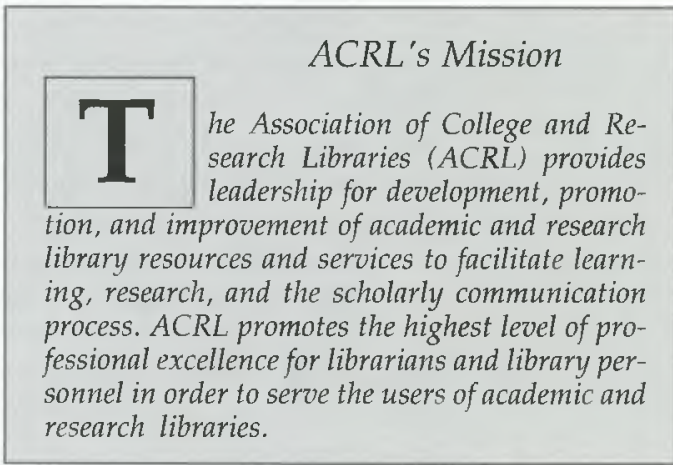

\section{ACRL's Mission}

that communication process. Please, during this transition time read CERL News in a timely fashion and keep up with your e-mail! If you have questions or concerns, don't wait until you are at Midwinter or Annual Conference, let the ACRL staff or me know.

This year is the first step forward into ACRL's future. Be an active participant! 


\section{Letter from the Executive Director}

\section{Althea H. Jenkins \\ EXECUTIVE DiRECTOR}

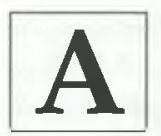

s our ACRL officers have observed, there are many challenges and opportunities facing both ACRL and the academic library community it serves. Changes in the way information is created, valued, shared, controlled, transmitted, pro-

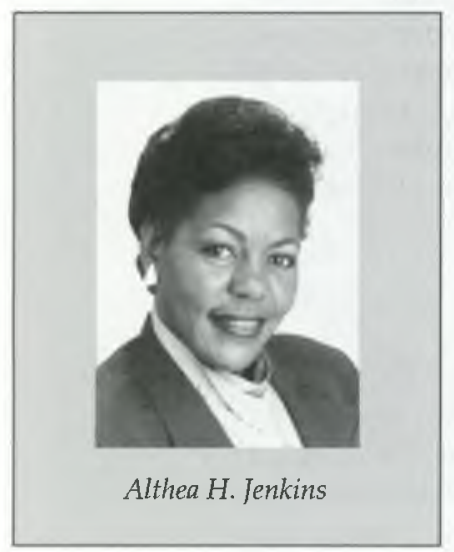
tected, distributed, and exchanged have created new requirements for the library and information profession. To position academic librarians and libraries to be responsive in a changing information environment and to choose their own destiny, ACRL undertook an aggressive planning process involving the entire association leadership: section chairs and vice-chairs, committee chairs, Chapters Council chair and vice-chair, the Planning Committee, and the Board of Directors. At various stages of the planning process, the entire membership was given the opportunity to review and comment on planning documents. At its final meeting for 1994-95 the ACRL Board of Directors approved the Strategic Plan, a "work in progress."

Although the strategic planning process was a key focus for the year, the ACRL membership was successful in focusing on other priority areas as well. On the pages that follow we will provide a glimpse of the year's programs and activities, but two activities deserve special mention on this page.

First, the National Conferences are major contributors to ACRL's visibility and status in the library and higher education communities. The conferences contribute to ACRL's reputation, financial good health, and professional development effectiveness. They have become stronger and more far-reaching with each conference. This year ACRL sponsored a very successful Seventh National Conference in Pittsburgh from March 29 through April 1, 1995.

Second, as ACRL carried out its strategic planning process, it developed an ambitious agenda to identify allies and partners and to utilize the power of connections. To this end, several partnering initiatives were launched throughout the year including: the information literacy study with six regional accrediting agencies, the Equal Access to Software Information (EASI) workshop with the American Association for Higher Education (AAHE), and the Building Community Information Organizations (CIO) initiative with the University of Illinois at Chicago. 


\section{Letter from the Executive Director}

As with all annual reports, this one is only a snapshot of the association's activities and programs that took place throughout the year. I am pleased to present to you this look into the life of ACRL in 1994-95.

It is the strength of member commitment that drives the association and brings the success that we all can celebrate. ACRL expresses appreciation and thanks to its members, leaders, sponsors, and dedicated staff for the support, enthusiasm, and creativity they brought to its programs and services.

\section{ACRL Staff}

Call us toll free at 1-(800) 545-2433 ext. XXXX or call us direct at (312) 280-XXXX or try our e-mail addresses

- Jack Briody, program assistant, 2516; jack.briody@ala.org

- Darlena Davis, administrative secretary, 2519; darlena.davis@ala.org

- Mary Ellen K. Davis, senior associate executive director, 2511; mary.ellen.davis@ala.org

- Francine Graf, managing editor, Choice magazine, (860) 347-6933; frangraf@delphi.com

- Noreen Hale, associate executive director for special programs and advancement, 2510; noreen.hale@ala.org

- Jack Helbig, classified ad manager, C\&RL News, 2513; jack.helbig@ala.org

- Althea H. Jenkins, executive director, 3248; althea.jenkins@ala.org

- Irving Rockwood, editor and publisher, Choice magazine, (860) 347-6933; irv_rockwood@delphi.com

- Pam Spiegel, production editor, ACRL journals, 2524; pam.spiegel@ala.org

- Michael Sterling, registration coordinator, 2515; michael.sterling@ala.org

- Cynthia Taylor, administrative secretary, 2521; cynthia.taylor@ala.org

- Hugh Thompson, program officer, 2517; hugh.thompson@ala.org

- Elisa Topper, director of membership services, 2523; elisa.topper@ala.org

Association of College and Research Libraries (ACRL), A Division of the American Library Association, 50 East Huron St., Chicago, IL 60611-2795; fax: (312) 280-2520 


\section{The Year in Review}

\section{Preparing to Lead}

\section{A}

CRL strengthened its capacity to serve its members, the academic library profession, and the higher education community in 1995. The strategic planning process provided opportunities for the membership to rethink roles and structures, and focus on the future. The ACRL Board of Directors approved a Strategic Plan that consists of a mission and vision statement, a set of goals and strategic directions designed to guide the association's decisions, programs, and activities.

Top priorities for ACRLFY 1995

- To provide leadership for the higher education community on library and information issues.

- To strengthen the association's commitment to diversity.

- To identify programs and delivery mechanisms that will enhance the ability of academic librarians serving the information needs of the higher education community.

- To use the information obtained from the membership survey and the Midwinter planning session to update the Strategic Plan.

- Toincrease the association's slectronic communication capabilities.
The ACRL Strategic Plan is a "work in progress." The Board will keep abreast of trends affecting the academic library profession and ACRL, and update the Strategic Plan in response.

ACRL responded to its priority to "provide leadership for the higher education community on library and information issues." Recognizing that if academic libraries were to be considered agencies essential to the educational, social, cultural, and economic life of higher education, the librarians who direct and manage their resources and services must be perceived as leaders. Two programs during the year focused on "Librarians As Leaders." At the ALA Midwinter Meeting in Philadelphia, ACRL sponsored a discussion session focusing on leadership in the library profession.

A preconference at the National Conference in Pittsburgh on March 28, 1995, called "Librarians As Campus Leaders," gave librarians a view of their expanded leadership roles by having them talk with librarians who were recognized campus leaders and to hear from their academic administrators what it was that made these librarians campus leaders.

The Board of Directors established the "ACRL Leadership Center" which will serve as a clearinghouse for information on leadership, and centralize and coordinate activities and programs that focus on academic librarians as leaders. 


\section{The Year in Review}

\section{Developing the Profession}

$\mathbf{M}$

any ACRL members participated in activities of committees, sections, chapters, special task forces, and discussion groups.

As new member units were established in 1995, some member units were eliminated or altered to facilitate the accomplishment of the mission, vision, and goals of the Strategic Plan.

Current concerns within academia regarding the increasing use and integration of information technology into the teaching/learning process have led to the establishment of special focus groups by a number of national associations. Academic librarians have been recognized as a group that is well versed in issues and trends of scholarly communication and information technology and are being invited to participate. In keeping with ALA Goal 2000 and the new ACRL Strategic Plan, ACRL established a new discussion group, "Alliances for New Directions in Teaching/Learning," to provide a forum for discussion of issues and trends and to share information from discussions among the new special focus groups.

The charges and compositions for the Membership and Professional Liaison Committees were revised and updated. The Professional Liaison Committee became the Council of Liaisons. Two advisory committees and one task force were appointed. The Bibliographic Instruction Section membership voted a name change to the Instruction Section. A second discussion group, "Electronic Reserves in Libraries" was also established.

The Bibliographic Instruction Section repackaged materials from its 1994 preconference, "Integrating Active Learning into Library Instruction: Practical Information for Immediate Use," and made them available to state library associations, library schools, clearinghouses, and individual librarians on request.

The College Libraries Section, through a grant from the Council on Library Resources, completed a third year of its "College Library Directors" mentor program. The 1995 program had 15 mentees and 15 mentors. The program was designed to enhance the leadership capabilities of newly appointed college library directors.

The Science and Technology Section received approval by the Standards Development Committee of NISO for its proposal to develop an American National Standard for "Title Page Information for Conference Proceedings." 


\section{The Year in Review}

ACRL continued its long-standing tradition of recognizing outstanding achievement among academic librarians and supporting research and publication through its awards program. One new award, the Marta Lange/CQ award recognizing achievement in law and political science librarianship, was approved. The award is administered by the LPSS. The most prestigious award presented to an academic librarian is ACRL's Academic/Research Librarian of the Year Award. The 1995 award was presented to Joseph A. Boissé, University

\section{ACRL Award Winners, 1995}

- Academic/Research Librarian of the Year Award (Donor: Baker \& Taylor Books)

Joseph Boissé, University of CaliforniaSanta Barbara

- ACRL/ALCTS/LAMA/LITA Hugh C. Atkinson Memorial Award

Nancy L. Eaton, Iowa State University

- K. G. Saur Award for Best C\&RL Article

Charles A. Schwartz, Rice University

- Miriam Dudley Bibliographic Instruction Librarian of the Year (Donor: Mountainside Publishing Co.)

Lizabeth (Betsy) Wilson, University of Washington

- The Katharine Kyes Leab and Daniel J. Leab American Book Prices Current Exhibition Catalogue Awards Expensive: "History in Deed: Medieval Society and the Law in England, 1100 1600," Harvard Law School Library; Inexpensive: "Eric Gill: The Cell of Good Living," Houghton Library, Harvard University. Honorable Mention, division one: "J. K. Lilly Ir.: Bibliophile," Lilly Library, Indiana University. Special Award of Merit: "The Last Best Hope of Earth: Abraham Lincoln and the Promise of America," Huntington Library

- Oberly Award for Bibliography in the Agricultural Sciences

"Guide to the Zoological Literature: The Animal Kingdom," George H. Bell and Diane B. Rhodes

- EBSCO Community College Leaming Resources Achievement Awards
(Donor: EBSCO Subscription Services) Leadership or Community Service: W. Lee Hisle, Austin Community College; Program Development: Derrie B. Roark, Hillsborough Community College

- Samuel Lazerow Fellowship for Research in Acquisitions or Technical Services (Donor: Institute for Scientific Information)

Karen A. Schmidt, University of Illinois at Urbana-Champaign

- Martinus Nijhoff West European Specialists Study Grant

Barbara Halporn, Harvard College

- Distinguished Education and Behavioral Sciences Librarian Award Hannelore B. Rader, Cleveland State University

- Doctoral Dissertation Fellowship (Donor: Institute for Scientific Information)

Danuta Nitecki, University of Maryland

- Instruction Section Publication of the Year

Frances F. Jacobson, University Laboratory High School Library at the University of Illinois at Urbana-Champaign, and Michael I. Jacobson, Vanderbilt University

Instruction Section Innovation in Instruction Award

UWired Freshman Interest Groups (FIGS), University of Washington, Seattle

- Rare Books \& Manuscripts Librarianship Award for Best Article Richard Oram, University of Texas 


\section{The Year in Review}

\section{Annual Conference Programs and Preconferences}

- Anthropology and Sociology (ANSS)_"Publishing the Social Text: Issues in Sociology and Anthropology Publication and Reviewing"

- Arts (ARTS) - "Diverse Images of Chicago Dance: From Cooperative Preservation to Cutting Edge"

- Asian, African, and Middle Eastern (AAMES), Afro-American Studies Librarians (AFAS), Anthropology and Sociology (ANSS), ACRL International Relations Committee, and ALCTS Committee on Cataloging Asian and African Materials-"Africa at the Field Museum: Perspectives on the New Permanent Africa Exhibit"

- Association of College and Research Libraries (ACRL)-_"Toward the Digital Library: Academic Library Futures"

- Bibliographic Instruction (BIS), ACRL Research Committee, and ALA Library Instruction Round Table_- "Measuring Up! Improving Instruction Through Evaluation"

- College Libraries (CLS) and University Libraries (ULS) — "Run Ragged by Riches! Technology and Changing Communications for the Library"

- Community and Junior College Libraries (CJCLS)_"Lyman Shepard as Frank Lloyd Wright: A Dramatic Presentation" and "Stepping Towards the Virtual Library: Planning, Practice, and Dreans"

- Copyright Committee, ALA Ad Hoc Subcommittee on Copyright, and LITA- "Copyright $A B C^{\prime}$ 's-Sources of Copyright Information"

- Education and Behavioral Sciences (EBSS)_"Distance Education in the 21st Century: Removing Campus Walls"

- English and American Literature (EALS) - "The Humanist and the Librarian: Creating a Collaborative Partnership"

- Extended Campus Library Services (ECLS)_ "Can This Marriage Be Saved? Academic and Public Librarians Working Together to Support Extended-Campus Students"

- Law and Political Science (LPSS)_"The United Nations at 50: Information Services, Policies, and Documentation"

- Media Resources Committee-"The Great Media Convergence: Evolving Relationships Between Campus Media and Information Systems and Services"

- President's Program - "The Life of the Mind in the 21st Century"

- Rare Books and Manuscripts (RBMS) - "The Age of Anxiety: Balancing Scholarly Needs for Primary Research Materials and Electronic Information" and "Collecting Cultures: The Politics and Practice of Building Special Collections," the 36 th RBMS Preconference

- Science and Technology (STS), ALCTS Preservation and Reformatting Section, and ALCTS Collection Development and Management Section- "Preserving the Record of Science and Technology: A Call to Action"

- Slavic and East European Section (SEES)_-Librarians Riding the Bear: Keeping Pace with Russian Publishing"

- University Libraries (ULS) and College Libraries (CLS)_-"But What About Me? The Human Face of Organizational Change

- Western European Specialists (WESS) - "European Connections: Electronic Resources for Western Europe"

- Women's Studies (WSS)_- New Feminist Research in Library and Information Science: Implications for Librarianship" 


\section{The Year in Review}

Librarian, University of California, Santa Barbara. In choosing Boissé for this award, the committee cited "his contribution to academic librarianship through his service, publication, and public presentations, and his role in creating model programs in library instruction and library diversity."

ACRL held its Seventh National Conference, "Continuity and Transformation: The Promise of Confluence," March 29-April 1, 1995, in Pittsburgh, Pennsylvania. The conference chair was Joanne Euster, University Librarian, University of California, Irvine. The conference attracted 2,721 participants and set a number of records. Nearly 1,800 librarians registered, representing all 50 states and eight foreign countries. More than 300 attendees shared ideas in 31 roundtable discussions, a new program offered at the National Conference. ACRL introduced its first Silent Auction with 62 items ranging from getaway weekends to books describing regional lifestyles. The National Conference was programmatically and financially successful.

The Rare Books and Manuscripts Section (RBMS) held its 36th preconference. "Collecting Cultures: The Politics and Practice of Building Special Collections" was held at Indiana University, Bloomington, from June 20 to 23 , and attracted 210 participants, 10 of whom were students. The preconference was programmatically and financially successful.

ACRL's committees and sections presented 20 programs at the 1995 ALA Annual Conference. A variety of topics were covered ranging from "The Life of the Mind in the 21st Century" to "Preserving the Record of Science and Technology." The Law and Political Science Section celebrated its 35th anniversary in 1995.

ACRL chapters provide programs and maintain an ACRL presence at the local level. Chapters held more than 34 programs in 199495. Several chapters developed strategic plans and explored ways to reinforce their link with ACRL national. 


\section{The Year in Review}

\section{SETting The Standard}

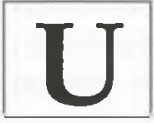

pdating and disseminating standards and guidelines that assist library staffs in delivering good services continued to be a key activity for some of ACRL's sections. Three ACRL official documents were revised: "Standards for Community, Junior, and Technical College Learning Resources Programs," published in CERL News in October 1994; "Standards for College Libraries," published in April 1995; and "Guidelines Regarding Thefts in Libraries," published in November 1994.

ACRL units produced and distributed several advisory lists to the academic community in 1995. Most notable among them were:

- "Faculty Status Consultants: Database of Experts," developed by the Academic Status Committee;

- "Resource List of Regional Accreditation Advisors Resource People," developed by the Standards and Accreditation Committee.

The College Libraries and Extended Campus Libraries Sections developed research agendas for their respective audiences.

ACRL staff handled more than 15,000 inquiries from membership and the academic library and higher education communities covering a variety of topics.

ACRL Official

Documents Published in 1994-95

- Standards for College $\mathrm{Li}$ braries, prepared by ACRL/CLS Standards Committee

- Standards for Community, Junior, and Technical College Learning Resources Programs, prepared by a joint committee of ACRL and AECT

- Guidelines Regarding Thefts in Libraries, prepared by the ACRL/ RBMSSecurity Committee

The information contained in the 25 published official ACRL documents in the form of standards, guidelines, and statements is useful in responding to a majority of the questions staff receive.

ACRL maintained a presence on the ALA gopher posting such documents as the Guide to Policies and Procedures, awards, conference announcements, and standards. ACRL added two new listservs in 1995 to facilitate the joint work of the Board and the Planning Committee: ACRL-BD and ACRL-Plan. The ACRL Nashville National Conference Executive Committee set up a homepage, as did several other ACRL units.

ACRL commented on the "fair proceedings of the fair use guidelines for higher education" through its Copyright Committee chair who attended the conference sponsored by the Patents and Trademark Office. 


\section{The Year in Review}

\section{Building Partnerships}

I nfluencing information policy development and partnering with higher education associations to achieve mutual interests received high priority in ACRL as the planning process developed. Several programs and activities were either completed or initiated in 1994-95.

The ACRL Board of Directors enthusiastically endorsed a resolution supporting the ALA Goal 2000 Initiative, including the proposed 1996 ALA dues increase. To exhibit its enthusiasm for the ALA Goal 2000 , the Board announced a pledge to the Fund

ACRL's Key Partnering Organizations

- National Forum on Information Literacy

- American Association of Higher Education

- American Council on Education

- Association of American Colleges and Universities

- American Association of Community Colleges

- Council of Independent Colleges

- National University Continuing Education Association

- American Association of University Professors

- National Association of State Universities and Land-Grant Colleges for America's Libraries in support of the ALA Office for Information Technology Policy.

ACRL cosponsored "Soaring to Excellence," a series of ten teleconferences for library technical assistants made possible by a $\$ 125,000$ grant from the U.S. Department of Education's Library Education and Human Resources Development Program. The teleconferences were broadcast by satellite from February to June 1995 by the National Institute for Library Personnel at the College of DuPage (COD), Glen Ellyn, Illinois. The interactive teleconferences were designed to provide library technical assistants with a basic understanding of practices, issues, and concerns being faced in today's libraries. The teleconferences attracted more than 10,000 library assistants at 412 viewer sites in the 50 states, Canada, Puerto Rico, and the Virgin Islands.

ACRL, in cooperation with the Middle States Association of Colleges and Schools, the Western Accrediting Commission for Senior Colleges and Universities, and the American Association of Higher Education (AAHE), engaged in an Information Literacy Data Collection Project to document the practices of schools in integrating information resources and technologies into higher education curricula across the United States. More than 800 institutions responded to the survey and two regional symposia were held in Philadelphia and Rochester for institutions that were known to have made progress toward institutionalizing information literacy. The Middle States Association prepared a report of the results for distribution. 


\section{The Year in Review}

ACRL established the Community Information Organizations (CIO) Initiative with the University of Illinois at Chicago, which proposes to develop structured training modules and workshops across the United States on accessing public information. The project proposes to place librarians in leadership roles working directly with government agencies, public organizations, local businesses, and other community groups to assure the promise of an equitable distribution of public information and services. An advisory committee was appointed to support the work of CIO. The committee began developing the framework for the initiative.

ACRL engaged in a cooperative project with AAHE to jointly sponsor a three-week online workshop with its Equal Access to Software and Information (EASI) Unit. An ACRL/EASI Advisory Committee developed an outline for the project, a proposal to seek funding, and defined the content of the workshops.

The ACRL Instruction Section (IS) Emerging Technologies Committee cooperated with the Coalition for Networked Information (CNI) to conduct a study on "User Education for the Internet." A report with recommendations was accepted by the Board of Directors.

ACRL identified nine key higher education organizations with which it will share ideas and implement programs in areas of mutual interest. These organizations will be assigned ACRL member liaisons who will make up the ACRL Council of Liaisons.

ACRL accepted an invitation for membership in the Library of Congress' Network Advisory Committee (NAC). 


\section{The Year in Review}

\section{Publications}

\section{A}

CRL maintained its vigorous publications program and continued its expansion into electronic publishing and communication. Total sales for books and net reverues for advertising and books for 1994-95 have been excellent. Significant additional sales and revenue have been realized by marketing ACRL titles through the ALA approval plans. Distribution through both the ACRL and ALA approval plans has resulted in guaranteed sales in the range of 300 to 400 copies. A major project was the publication of Vocational and Technical Resources for Community Col-

\section{ACRL Journals}

- Choice-Book review journal of ACRL; 11 issues per year (July/ August combined).

- College \& Research Libraries-.-Official journal of ACRL; six bimonthly issues per year.

- College \& Research Libraries News-Official news magazine of ACRL; 11 issues per year (July/August combined).

- Rare Books and Manuscripts Librarianship A journal of theory and practice covering all aspects of special collections librarianship; two issues per year. lege Libraries as a joint venture with Choice magazine. Edited by Mary Ann Laun and produced at Choice, this 622-page publication has been well receivedreviews have been positive and sales brisk. Another significant title was Continuity and Transformation: The Promise of Confluence: Proceedings of ACRL's 7th National Conference, edited by Richard AmRhein.

Upon a recommendation of the Publications Committee, ACRL staff took over production of $\mathrm{Col}$ lege $\mathcal{E}$ Research Libraries last summer. The first issue from ACRL, which included some graphic redesign, was published in September 1995. After a nationwide search by a member search committee, Donald E. Riggs was named CERL editor to succeed Gloriana St. Clair when her term expires in July 1996.

In the electronic publishing arena, $C \mathcal{E} R L$ NewsNet, the abbreviated electronic version of CERL News, was expanded to include the series of articles on Internet resources that has been running monthly in the News.

\section{CHOICE}

This was a year of significant change for Choice, continuing progress with office automation and technology, and major accomplishments with two special publications.

Subscriptions to the magazine and Reviews on Cards remains stable, with combined subscriptions remaining just under 5,000. Site licenses to Choice's SilverPlatter CD-ROM and the reviews database with the CARL Corp., as well as royalties from the Bowker Books in Print Plus publication, continue to be a small but growing source of revenue for Choice. In addition, more third parties are expressing interest in 


\section{The Year in Review}

licensing Choice reviews, resulting in ongoing evaluation and negotiation of new proposals.

The much-awaited publication of a major new book was completed during the year. Work concluded on the 11th edition of the Guide to Reference Books, edited by Robert Balay while on leave from his regular responsibilities as Choice Reference Editor. Choice's second special project, Vocational and Technical Resources for Community College Libraries, is described on the previous page.

Choice's electronic publishing system continues to advance and this year it was enhanced by the development of a publisher database, which automated several key procedures: maintaining and updating information on relevant publishers; mailing review copies to publishers; and generating special mailings and other marketing activities.

The Advertising Department was another area of major change. Art Beck, Advertising Sales Manager for Choice as well as Booklist and Book Links, left to become an independent sales representative, and continues to represent Booklist and Book Links. Art, who was with Choice for more than 14 years, was instrumental to Choice's financial success; we certainly miss him, but we wish him much success in his new venture.

Stuart Foster was appointed new

New Titles from ACRL in 1995

- Managing Student Workers in College Libraries, CLIP Note \#22, Michael Kathman and Jane McGurn Kathman, comps.

- Discovering Librarians: Profiles of a Profession, Mary Jane Scherdin, ed.

- Library Services for Non-Affiliated Patrons, CLIP Note \#21, Eugene S. Mitchell, comp.

- Science and Engineering Conference Proceedings: A Guide to Sources for Identification and Verification, Barbara DeFelice, ed.

- Vocational and Technical Resources for Community College Libraries, Mary Ann Laun, ed.

- Internet Resources: A Subject Guide, reprinted from $C \& R L$ News, Hugh A. Thompson, comp.

- Continuity and Transformation: The Promise of Confluence: Proceedings of ACRL's 7th National Conference, Richard AmRhein, ed.

Advertising Sales Manager for Choice in June 1995. Over the past four years he successfully managed advertising sales for other ACRL and ALA division journals at Choice's Connecticut location. In his new position he continues to manage advertising sales for all ACRL journals in addition to Choice. 


\section{ACRL Board of Directors, 1994-95}

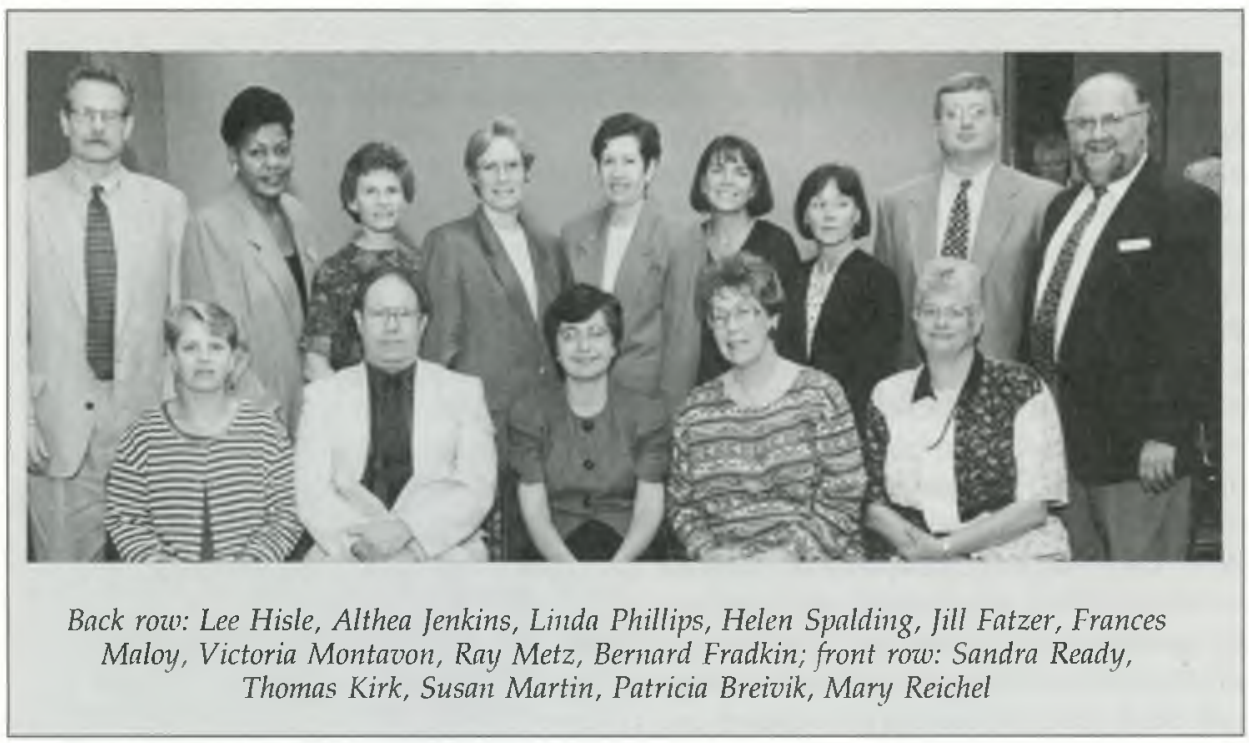

\begin{tabular}{|l|} 
ACRL Board of Directors, 1994-95 \\
President: \\
Susan K. Martin, Georgetown University \\
Vice-President/President-Elect: \\
Patricia Senn Breivik, Wayne State University \\
Past-President: \\
Thomas G. Kirk, Earlham College \\
Budget E Finance Committee Chair: \\
Helen Spalding, University of Missouri, Kansas City \\
ACRL Councilor: \\
W. Lee Hisle, Austin Community College \\
Directors-at-Large: \\
Jill B. Fatzer, University of New Orleans \\
Bernard Fradkin, College of DuPage \\
Frances J. Maloy, Emory University \\
Ray E. Metz, Case Western Reserve University \\
Victoria A. Montavon, Saint Joseph's University \\
Linda L. Phillips, University of Tennessee \\
Mary Reichel, Appalachian State University \\
Planning Committee Chair (ex-officio): \\
Sandra Ready, Mankato State University \\
Executive Director (ex-officio): \\
Althea H. Jenkins, ACRL /ALA
\end{tabular}




\title{
Financial Report
}

\author{
HeLen Spalding \\ Budget and Finance Committee Chair
}

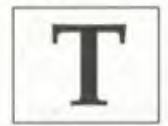

he ACRL 1995 fiscal year began on September 1, 1994, and ended on August 31, 1995, with positive operating fund balances in both the ACRL and Choice budgets.

- The actual ACRL revenues totalled \$1,829,950, which exceeded by $\$ 196,913$ what had been budgeted for 1995 . (Sources of revenues are membership dues, publications, and education programs.)

- ACRL's actual expenses for 1995 were $\$ 1,501,254$, which was $\$ 48,758$ less than budget.

- Although the revenues for Choice were $\$ 23,904$ less than budget, the expenses also were less than budget, resulting in net revenue for 1995 of $\$ 89,045$.

- The "Ending Reserve" categories at the top of the accompanying revenue spreadsheet represent funds available to the association in its major accounts at the end of the fiscal year.

- The ACRL Operating Fund balance at the end of FY95 is $\$ 1,146,057$, and will be used to fund the 1996 Mandated Operating Reserve and the projected 1996 budget deficit. (The Mandated Operating Reserve is $40 \%$ of average of the previous three completed fiscal

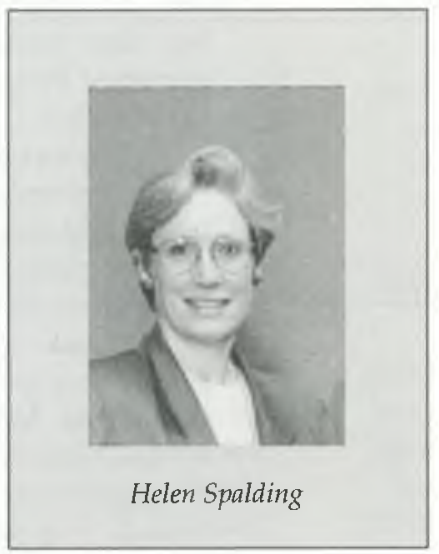
years' total expenses, and is required by ALA to cover unexpected budget reverses.)

- The Choice Operating Fund balance is $\$ 994,569$.

- The ACRL Endowments now total \$158,087, and include the following funds: ACRL, \$51,057; Hugh Atkinson Award, \$77,060; Leab Award, \$17,170; and Oberly Award, \$12,800.

- The Choice Endowment principal is $\$ 61,460$.

The success of the 1995 budget is due to several factors:

1) Staff costs and operating expenses being monitored by staff were lower than what had been budgeted.

2) Book sales revenues for 1995 were $\$ 93,491$ more than budget, and can be attributed in part to ACRL's participation in the ALA approval plan. Since the late 1980s, ACRL has had its own approval plan, currently consisting of approximately 140 purchasers. Since joining the ALA Approval Plan in 1994, pre-sales for each new ACRL title are approximately 350.

3) A steady increase in classified ads in CERL News may be due to the more positive condition of academic library staffing, positive 


\section{Financial Report}

results for libraries from advertising in the News, and the electronic connection to job ads through CERL NewsNet.

4) Product advertising and subscription revenues for CERL News and for $R B M L$ were $\$ 29,820$ more than budget, although both types of revenues were less than budget for $C \& R L$, and expenses for overall publications exceeded budget.

5) The National Conference in Pittsburgh was well attended and both registration and exhibit space rental revenues exceeded budget. The net revenue after the three-year planning and implementation of the conference totalled $\$ 120,396$.

6) Although Choice product advertising revenues were $\$ 112,800$ less than budget, subscription, royalties, pamphlet sales revenues exceeded budget, and Choice operating expenses were \$171,115 less than budget.

The association's implementation of the new Strategic Plan and new membership recruitment plan, examination of long-term financial trends and means to strengthen revenue sources, and development of exciting plans for the 1997 National Conference in Nashville, promise to maintain ACRL's current financial stability.

Thanks go to the ACRL staff for their efforts on behalf of the association, and to the 1994-95 members of the Budget and Finance Committee: Mignon Adams, Camila Alire, David Brink, Ray English, W. Lee Hisle, Andrea Hoffman, Janice Kemp, William Miller, Juana Young (intern), and Cathy Henderson (intern). Ex officio: Patricia Senn Breivik, Althea Jenkins. 


\section{Financial Report}

\section{Executive Summary 1994-95}

\begin{tabular}{|c|c|c|c|c|}
\hline SOURCES OF REVENUE & $\begin{array}{c}\text { FY1995 } \\
\text { BUDGET }\end{array}$ & $\begin{array}{l}\text { FY1995 } \\
\text { ACTUAL }\end{array}$ & $\begin{array}{l}\text { PERCENT } \\
\text { OF BUDGET }\end{array}$ & $\begin{array}{c}\text { LAST YEAR } \\
\text { FINAL } \\
\end{array}$ \\
\hline \multicolumn{5}{|l|}{ Ending Reserve } \\
\hline Operating Fund (ACRL) & $\$ 837,361$ & $\$ 1,146,057$ & $136.86 \%$ & $\$ 837,922$ \\
\hline Endowments (ACRL) & $\$ 114,514$ & $\$ 158,087$ & $138.05 \%$ & $\$ 114,514$ \\
\hline Operating Fund (CHOICE) & $\$ 925,130$ & $\$ 994,569$ & $107.50 \%$ & $\$ 925,130$ \\
\hline Endowment (CHOICE) & $\$ 32,227$ & $\$ 61,460$ & $190.70 \%$ & $\$ 32,227$ \\
\hline Subtotal & $\$ 1,909,232$ & $\$ 2,360,173$ & $123.61 \%$ & $\$ 1,909,793$ \\
\hline \multicolumn{5}{|c|}{ Membership dues and other } \\
\hline Dues & $\$ 370,026$ & $\$ 351,875$ & $95.09 \%$ & $\$ 346,866$ \\
\hline Other & $\$ 300$ & $\$ 9,767$ & $3256.66 \%$ & $\$ 6,653$ \\
\hline Advisory & $\$ 0$ & $\$ 0$ & $0.00 \%$ & $\$ 2,200$ \\
\hline Awards & $\$ 6,400$ & $\$ 4,950$ & $77.34 \%$ & $\$ 8,516$ \\
\hline Sec. Newsletters & $\$ 0$ & $\$ 2,430 \quad 2150$ & $0.00 \%$ & $\$ 0$ \\
\hline Subtotal & $\$ 376,726$ & $\$ 369,022$ & $97.95 \%$ & $\$ 364,235$ \\
\hline \multicolumn{5}{|l|}{ Publications } \\
\hline CHOICE & $\$ 1,591,500$ & $\$ 1,567,596$ & $98.49 \%$ & $\$ 1,536,515$ \\
\hline C\&RL & $\$ 137,187$ & $\$ 124,514$ & $90.76 \%$ & $\$ 115,347$ \\
\hline C\&RL News & $\$ 229,185$ & $\$ 319,916$ & $139.58 \%$ & $\$ 255,000$ \\
\hline RBML & $\$ 22,571$ & $\$ 28,909$ & $128.08 \%$ & $\$ 30,087$ \\
\hline Nonperiodical Pubs. & $\$ 90,500$ & $\$ 183,991$ & $203.30 \%$ & $\$ 153,999$ \\
\hline $\mathrm{BCL}$ & $\$ 0$ & $\$ 0$ & $0.00 \%$ & $\$ 3,600$ \\
\hline Subtotal & $\$ 2,070,943$ & $\$ 2,224,926$ & $107.43 \%$ & $\$ 2,094,548$ \\
\hline \multicolumn{5}{|l|}{ Education } \\
\hline National (95) & $\$ 703,063$ & $\$ 756,718$ & $107.63 \%$ & $\$ 0$ \\
\hline Pre- \& Postconferences & $\$ 73,805$ & $\$ 46,880$ & $63.51 \%$ & $\$ 63,316$ \\
\hline Subtotal & $\$ 776,868$ & $\$ 803,598$ & $103.44 \%$ & $\$ 63,316$ \\
\hline Total Revenue & $\$ 3,224,537$ & $\$ 3,397,546$ & $105.36 \%$ & $\$ 2,522,099$ \\
\hline CHOICE Revenue & $\$ 1,591,500$ & $\$ 1,567,596$ & $98.49 \%$ & $\$ 1,536,515$ \\
\hline Total Rev. W/O Choice & $\$ 1,633,037$ & $\$ 1,829,950$ & $112.05 \%$ & $\$ 985,584$ \\
\hline
\end{tabular}




\section{Financial Report}

\begin{tabular}{|c|c|c|c|c|}
\hline OBJECT OF EXPENSE & $\begin{array}{c}\text { FY1995 } \\
\text { BUDGET }\end{array}$ & $\begin{array}{l}\text { FY1995 } \\
\text { ACTUAL }\end{array}$ & $\begin{array}{c}\text { PERCENT } \\
\text { OF BUDGET }\end{array}$ & $\begin{array}{c}\text { LAST YEAR } \\
\text { FINAL }\end{array}$ \\
\hline \multicolumn{5}{|l|}{ Membership Activities } \\
\hline Membership Servs. & $\$ 54,823$ & $\$ 51,486$ & $93.91 \%$ & $\$ 48,701$ \\
\hline Exec. Comm. \& Board & $\$ 67,783$ & $\$ 87,353$ & $128.87 \%$ & $\$ 62,153$ \\
\hline Statistics & $\$ 0$ & $\$ 2$ & $0.00 \%$ & $\$ 12,471$ \\
\hline Advisory & $\$ 24,822$ & $\$ 22,774$ & $91.74 \%$ & $\$ 18,433$ \\
\hline Standards distrib. & $\$ 8,046$ & $\$ 5,365$ & $66.67 \%$ & $\$ 4,197$ \\
\hline Discussion Groups & $\$ 2,764$ & $\$ 2,702$ & $97.75 \%$ & $\$ 2,079$ \\
\hline Awards & $\$ 16,225$ & $\$ 17,038$ & $105.01 \%$ & $\$ 17,284$ \\
\hline Chapters & $\$ 59,071$ & $\$ 48,554$ & $82.19 \%$ & $\$ 37,882$ \\
\hline Committees & $\$ 52,170$ & $\$ 52,441$ & $100.51 \%$ & $\$ 41,649$ \\
\hline Sections & $\$ 66,810$ & $\$ 59,408$ & $88.92 \%$ & $\$ 45,781$ \\
\hline Section Newsletters & $\$ 26,255$ & $\$ 23,289$ & $88.70 \%$ & $\$ 23,337$ \\
\hline Chapter Topics & $\$ 4,599$ & $\$ 2,944$ & $64.01 \%$ & $\$ 2,633$ \\
\hline C\&RL & $\$ 4,795$ & $\$ 0$ & $0.00 \%$ & $\$ 3,751$ \\
\hline C\&RL News & $\$ 36,614$ & so & $0.00 \%$ & $\$ 0$ \\
\hline Subtotal & $\$ 424,777$ & $\$ 373,356$ & $87.89 \%$ & $\$ 320,351$ \\
\hline \multicolumn{5}{|l|}{ Publications } \\
\hline CHOICE & $\$ 1,649,666$ & $\$ 1,478,551$ & $89.62 \%$ & $\$ 1,459,458$ \\
\hline C\&RL & $\$ 137,187$ & $\$ 123,953$ & $90.35 \%$ & $\$ 115,347$ \\
\hline C\&RL News & $\$ 229,185$ & $\$ 263,486$ & $114.96 \%$ & $\$ 227,232$ \\
\hline RBML & $\$ 21,865$ & $\$ 22,694$ & $103.79 \%$ & $\$ 22,118$ \\
\hline Nonperiodical Pubs. & $\$ 89,941$ & $\$ 108,463$ & $120.59 \%$ & $\$ 92,286$ \\
\hline Subtotal & $\$ 2,127,844$ & $\$ 1,997,147$ & $93.85 \%$ & $\$ 1,916,441$ \\
\hline \multicolumn{5}{|l|}{ Education } \\
\hline National (95) & $\$ 537,518$ & $\$ 529,788$ & $98.56 \%$ & $\$ 88,488$ \\
\hline Pre- \& Postconferences & $\$ 73,805$ & $\$ 40,548$ & $54.93 \%$ & $\$ 70,769$ \\
\hline National (97) & $\$ 35,734$ & $\$ 23,134$ & $64.73 \%$ & $\$ 0$ \\
\hline Subtotal & $\$ 647,057$ & $\$ 593,470$ & $91.71 \%$ & $\$ 159,257$ \\
\hline
\end{tabular}

\section{Special Programs}

Information Literacy

$\mathrm{ClO}$

$\$ 0$

$\$ 10,894$

$0.00 \%$

$\$ 0$

$\$ 0 \quad \$ 4,938$

$0.00 \%$

\$0

Subtotal
TOTAL EXPENSES

CHOICE Expenses

TOTAL EXP. W/O CHOICE

CHOICE Net
$\$ 0$
$\$ 3,199,678$

$\$ 1,649,666$

$\$ 1,550,012$

$(\$ 58,166)$
$\$ 15,832$

$0.00 \%$

\$O

Net w/o CHOICE

$\$ 83,025$

$\$ 2,979,805$
$\$ 1,478,551$
$\$ 1,501,254$
$\$ 89,045$

$93.12 \%$

$\$ 2,396,049$

$89.62 \% \quad \$ 1,459,458$

$96.85 \% \quad \$ 936,591$

$-153.08 \%$

$\$ 77,057$ 


\section{Financial Report}

\section{ACRL Colleagues \\ (CORPORATE AND FOUNDATION SUPPORT)}

ACRL thanks the corporate community for financially supporting its activities and programs throughout the year. Working together, the academic library and corporate communities can achieve goals of mutual interest. Librarians benefit from the expert analysis and problem-solving corporate leaders can bring to issues and topics being addressed.

Corporate contributions added $\$ 48,217$ to the ACRL 199495 budget. It was because of these contributions that the ACRL membership enjoyed a wider range of programs and activities. ACRL could not be the major player in the library and higher education arena that it is without the cooperation received from sponsorships.

ACRL's Colleagues Program recognizes corporate supporters as "Summa Cum Laude" (donations of $\$ 5,000$ or more), "Magna Cum Laude" $(\$ 1,000-$ $\$ 5,000)$, and "Cum Laude" ( $\$ 500$ $\$ 1,000)$.

\section{ACRL Colleagues}

Summa Cum Laude $\mathbf{( \$ 5 , 0 0 0}$ or more)

Ameritech

Apple Computer, Inc.

Bell Atlantic of Pennsylvania

Carnegie Mellon University's

Computing Services \&

University Libraries Staff

Chadwyck-Healy, Inc.

EBSCO Subscription Services

Prepnet

\section{Magna Cum Laude $(\$ 1,000-\$ 5,000)$}

Blackwell North America

Congressional Quarterly

The Faxon Company

Information Access Company

Research Publications International

Serendipity Books

H.W. Wilson Company

University Microfilms, Inc. (UMI)

Yankee Book Peddler, Inc

\section{Cum Laude $(\$ 500-\$ 1,000)$}

Baker \& Taylor Books

Biological Abstracts, Inc.

Bromer Booksellers

CARL Corporation \& UnCover Co.

Chemical Abstracts Service Division

DBA Lame Duck Books

Elsevier Science, Inc.

Historicana

Institute for Scientific Information

Ken Lopez \& Pamela K. Drecler

Lena Minkoff Memorial Fund, Inc.

Midwest Library Service

Elizabeth Phillips

Phillip J. Pirages

Rulon-Miller Books, Inc.

K.G. Saur

Thomas Schwartz

SIRSI Corporation

Softline Information, Inc.

Swann Galleries

University Archives

William Reese Company

Ximenes: Rare Books, Inc. 
Subscribe to this unprecedented reference if you seek to take advantage of the Internet for your library's needs!

\section{Internet Reference Services Quarterly}

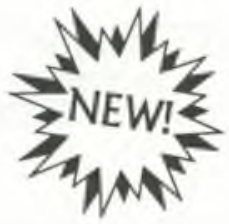

the journal of innovative information practice, technologies, and resources

\section{Editor: Lyn Elizabeth M. Martin, MLS}

Senior Assistant Librarian and Cataloger, Learning Resources Center,

State University of New York (SUNY), Cobleskill

Book Review Editor: Heather Blenkinsopp, MLS, MS

$\mathbf{T}$ his new journal will be the key to practical and theoretical applications and resources of the Internet for all aspects of librarianship: administra. tive services, reference services, interlibrary loan, acquisitions, collection development, bibliographic instruction, cataloging, etc., as practiced in all types (research, academic, public, school, special, and corporate) and all sizes (large to small, even one person) of libraries.

Topics in the Internet Reference Services Quarterly will open new channels of information as articles will highlight theoretical, research, and practical application of Internet-related information services, sources, and resources. A book review section is planned to give both fulllength, feature reviews and short, synopsis reviews on Internet-related monographs and serials of growing interest to librarians and libraries. "Hot" bibliographies on emerging Internet topics of special interest and value for librarians and libraries are also planned into this new journal.

\section{FREE SAMPLE COPIES!}

SAMPLE COPIES OF JOURNALS ARE AVAILABLE FREE OF CHARGE to libraries. Please send pour request on your institutional letterhead to Sample Copy Department, The Haworth Press, Inc., 10 Alice Street. Binghamton, NY 139041580 USA.

"AT LAST, A PRINT MAP FOR
EXPLORING THE REFERENCE
QUADRANT OF THE INTERNET
UNIVERSE. This journal will serve as a
guide for those tibrarians and informa.
tion scientists who are redefining
libraries and library services."
James W. Galloway. PhD. Assistant Director of
Libraries for Research Services, Texas Woman's
University
"The quality of the contents is impres-
sive. ... THOUGHT.PROVOKING
READINC FOR ANYONE WHO NEEDS
TO KNOW MORE ABOUT THE
INTERNET AND HOW IT IMPACTS
LIBRARIES."
Kathy Tomajko, MLn, Head, Reference
Department, Library and Information Center,
Georgia Institute of Technology

9 The Haworth Press, inc.

10 Alice Street, Binghamton. NY 13904-1580 USA

Tel: 1-800-342-9678 / Fax: 1-800-895-0582 / E-mail: getinfo@haworth.com 


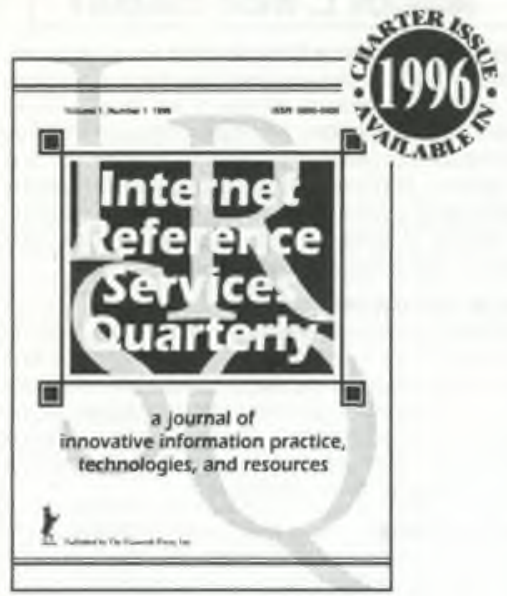

Meet the Editor ....

Lyn Elizabeth M. Martin, MLS, holds a BA in English from the College of St. Rose and an MLS from the University at Albany. She is currently Catalog Librarian at the State University of New York College of Agriculture and Technology at Cobleskill, where her position includes cataloging and authority control as well as bibliographic instruction at the reference desk and at Internet, CD-ROM, and OPAC terminals. Ms. Martin is also a teacher and mentor for library and information science graduate interns. Ms. Martin has written numerous articles and has spoken widely on a broad range of library-related topics (including the Internet), covering and bridging library technical and public services.

\section{Contributions Welcome...}

Potential authors should contact the editor via Email for a detailed "Instructions for Authors" brochure: martinlm@snycob.cobleskill.edu, or via mail or telephone: Lyn Elizabeth M. Martin, MLS, Senior Assistant Librarian and Cataloger, LRC/Jared Van Wagenen Hall, SUNY Cobleskill, Cobleskill, NY 12043; Tel: (518) 234-5887 or -5841 .

\section{A Breadth of Topics...}

\section{Selected Contents from Volume 1:}

Introduction to the Charter Issue A5C4DE2IL3MNOR2SU2 (AK-DELEM-NOR-

SU): Decoding the Library Profession's

Response to Emerging Networked Resources

What Are They Doing With the Internet?

A Study of User Information-Seeking

\section{Behaviors}

Using the Internet for Document Delivery

Use of the Internet via Universal Information

Access Workstation

Wiring the Trenches: Teaching Faculty and

Librarians Working Together on the Internet

The Dirty Details of Gopher Maintenance:

Department of Commerce Economic Data and

the University of Michigan Documents Center

Using World Wide Web Software for Reference and Instruction

Rare Book Catalogers and the Internet

The Impact on Reference Services of Networking CD-ROM Databases

A Proposal for Implementing Multi-User ObjectOriented Technology (MOO) in an Academic Library Setting

Evaluating Use of the Internet Among Academic Reference Librarians

Change and Challenge: The Impact of Emerging Technology on Library Services

Book Reviews

Cartoons

Selling the Home Page: An Essay on the World Wide Web and Rhetoric

Internet Primer: Workshop Design and Objectives

Homesteading on the Web: The Queensland Department of Education Virtual Library

Empowering Women: Creating a Women's

Presence on the Web

Internet Training: The Trainees' Thoughts

"Hot Bibliography": Everything You Always

Wanted to Know About HTML

Volume 1, No. 1-Spring 1996. Quarterly (4 issues). Volume 2, No. 1-Spring 1997. Quarterly (4 issues).

Subscription rates (per volume):

Individuals: \$36/ Institutions \& Libraries: \$48 